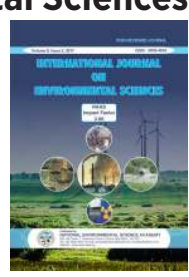

\title{
DISTRIBUTION AND COLLECTION PATTERN OF PICRORHIZA KURROOA MEDICINAL PLANT SPECIES OF NEPAL
}

\author{
Jit Narayan Sah ${ }^{1^{*}}$ and Mahesh Nepali ${ }^{2}$ \\ ${ }^{1}$ Institute of Forestry, Tribhuvan University, Kirtipur, Nepal \\ ${ }^{2}$ Province Government, Ministry of Industry, Tourism, Forest and Environment, \\ Forest and Environment Directorate, Surkhet, Nepal
}

\section{Research Article}

Received: 18.10.2021

Accepted: 28.10.2021

Published: 07.11.2021

\begin{abstract}
Medicinal flora is one of the important natural resources of Nepal. Picrorhiza kurrooa (Kutki) is a well-known medicinal herb found in high mountain of Nepal. The Kutki rhizomes have been widely used to cure indigestion problems in traditional medication systems. Very less information is available on its distribution and collection patterns, particularly from high mountain of mid-western of Nepal till date. The present research aimed to explore the distribution of Kutki and assess its collection pattern in Nepal. Primary data were collected through direct field survey and key informant interview. A total of 63 plots with each plot size of $5 \mathrm{~m} \times 5 \mathrm{~m}$ were laid out in the field to collect data. The stratified systematic sampling with sampling intensity $0.01 \%$ was adopted for distribution survey. The results revealed no significance difference in mean number of Kutki with respect to aspect ( $>0.05$ ), whereas there is significance difference in mean number of Kutki with respect to elevation $(p<0.05)$. The distribution of Kutki was recorded between $3750 \mathrm{~m}$ lower plot and $4831 \mathrm{~m}$ at higher plot. The Important Value Index of Kutki was found 113.59 with relative frequency of $34.44 \%$. The highest density of Kutki (7476.92 per hectare) was found on eastern aspect. Male participation was found higher than the female for collection of Kutki. Scientific harvesting technique should be adopted for sustainable management of Kutki in the study area.
\end{abstract}

Keywords: Important Value Index, medicinal flora, high mountain, Nepal, Picrorhiza kurrooa.

\section{INTRODUCTION}

Nepal's biodiversity is a reflection of its unique geographic position and variations in altitude and climate. The country's 35 forest types and 118 ecosystems are home to over $2 \%$ of the world's flowering plants, 9 percent of the world's bird species, 4 percent of the world's mammalian species, and an estimated 7,000 species of higher value plants-making Nepal the twenty-fifth most species-rich country in the world (Bhuju et al., 2007; MoFSC, 2009). In Nepal, most of commercially used herbs from the country are wild, organic and natural, though not certified. About 3000 species of the MAPs are traded internationally, among which 2000 of them are particularly traded in the European country like German, Switzerland and France. Global import of the MAPs is raised by $+3 \%$ since 2010 and reached in 2014 a volume of 673,564 tones that cost valued US\$2,724 million. The international market for MAPs is dominated by China, France, Italy, Germany, Japan, Spain, UK and USA (Schippmann et al., 2006). The importance of MAPs is even higher in recent years with the expansion of global herbal market, as Vasisht et al., (2016) estimated the annual trade of MAP materials to be US\$ 33 billion in 2014. Nepal's position in the center of the Himalaya enables it to host thousands of medicinal plants and is one of the major suppliers of MAPs to India since time immemorial. However, the quantification of trade had started few decades ago when Edwards (1996) estimated 10,000 tons of MAPs from more than 100 species was harvested from Nepal. Few years later, Olsen (2005); based on 1997/98 survey, estimated the export of 14500 tons of

*Corresponding author: jitnarayan2008@gmail.com 
crude MAPs worth US\$ 16 million to India and China. Recently, using the UNCOMTRADE data, Ghimire et al., (2015) estimated the export of 10770 tons of MAPs worth US\$ 60.09 million from Nepal.

Picrorhiza kurrooa Royle ex. Benth (family Scrophulariaceae) locally known as 'Kutki' is a medicinally revered perennial herb, distributed in the Himalayan region (Pakistan, India, Nepal, Bhutan and southern China) at an elevation ranging from 30005000m (Chettri et al., 2005; Sah and Varshney 2013; Sah et al., 2015).It has a long, creeping rootstock that is bitter in taste marked on its outer part with scaly leaves and cork exfoliates exposing in the black cortex and grows in rock crevices, moist and sandy soil, stony and grassy slopes and on the turf of glacial flats (Dutta at al., 2007). Picrorhiza kurrooa is listed in Appendix-II of the Convention on International Trade of Endangered Species of Wild Fauna and Flora (CITES). This species is protected for reducetion of $P$. kurrooa according to Protection act and its Regulations (Health Canada, 2015). The maximum richness of medicinal plants was found at an elevation of $1100 \mathrm{~m}$ but the maximum numbers of protected areas were found at elevations between $3000-3500 \mathrm{~m}$. This plant is uprooted from its natural habitat mature roots and rhizomes. More than $90 \%$ of its annual demand is fulfilled from the wild sources. Total 300 to 400 individual plants should be uprooted to get $1 \mathrm{~kg}$ dry weight of underground parts from this plant (Uniyal et al., 2011). Now the size of the wild population has been declining and being critically endangered as a result of overexploitation, habitat fragmentation, lack of organized cultivation practice, which reckless exploitation continues, therefore, this species has been listed as endangered species by international Union for Conservation of Nature and Natural Resources (Nayer and Sastri, 1990; Bantawa et al., 2011). It has also been categorized among the 37 identified as top priority species for conservation and cultivation in Western Himalaya because of narrow distribution range, small population size and high use value.

Picrorhiza kurrooa is among one of the topmost traded 15 plant species in India in relation to their economic value and more than $10,000 \mathrm{~kg}$ of their marketing takes place only in the Delhi market. The prices of $P$. kurrooa varied in range of IRs. 220-340 / kg during 2007-10 which is hiked up to IRs.475/kg in 2016 in Indian market (Shitizet al., 2013; Anonymous, 2016). India contributed only about 70 tons of $P$. kurrooa supply in context to global supply of 375 tons (excluding China and Pakistan) in their actual demand of 5000 tons annually which is mainly collected from Himachal Pradesh, Jammu and Kashmir, Uttarakhand and Sikkim to satisfy the demand of drug industries (Shitizet al., 2013). Hence, to fulfill the actual demands of 5000 tons and this is also going up year by year the study and conservation of $P$. kurrooa has become essential. A perusal of literature revealed that although $P$. kurrooa is very well known for its medicinal importance, but information regarding variability in active content (chemo-types) is scanty. Such information is essential in isolating better strains in terms of active content, understanding and further refinement of propagation. The perennial herb plant Kutki is used as official medicine and indigenous medicinal purpose. Nowadays, there is a revival of interest with herbal-based medicine due to the increasing realization of the health hazards associated with the indiscriminate use of modern medicine and the herbal drug industries is now very fast growing sector in the international market (Aryaet al., 2013). $P$. kurrooa has been demonstrated to possess multiple pharmacological activities such as Antiasthma-tic, Antioxidant, Anti-inflammatory, Anti-ulcer, Immunomodulatory, Anti-allergic, Anaphylactic, Antibacterial, Hepatoprotective, Immunomodulatory and Antidiabetic activity. (Vaghela et al., 2015).

It has been estimated that about 90 percent of nontimber forest products (NTFPs)/MAPs are harvested from the wild. About 80 percentages of the value and volume in trade is occupied by 20 high demand and high value products, most of the wild origin. Further, half the traded amount is covered by the transaction of five highly-traded NTFPs (Olsen et al., 2005). NTFPs are among the major exports of Nepal. Nepal itself is consuming herbal products on an annual increment of 20 percent (Ghimire et al., 2008). Therefore, proper management, production and diversification of NTFPs and its derivatives in rural areas of Nepal can help alleviate poverty by creating income generating opportunities locally (Pyakurel et al., 2011). Nepal is rich in terms of NTFPs resources with many products having industrial uses and potentials of exporting various levels of value added products. Medicinal plant has an important role in primary health care for local people livelihood whereas majority of household use medicinal plant for treating disorder and disease in Nepal. The fact that a wide range of such plant was collected at household levels mostly for domestic 
consumption, some for sale (Hesanet al., 2013).Most of the rural populations are partially or fully dependent on traditional medicines prepared from locally available herbs. On the other hand, the non- timber forest products of Nepal are declining rapidly due to the unscientific and unsustainable exploitation of the forest products. In the absence of proper management and control in collection and trade, NTFPs are going to be vulnerable, endangered and even extinct (Acharya at el., 2000). Practice of using plants and plants parts for medicinal use is decreasing because youngsters show less interest in traditional practices mainly due to less recognition of traditional healers and easy availability of modern medicines and instant effect (Acharya, et al., 2012). Most of the NTFPs from Jumla are collect by shepherds and other lower caste people for make handsome money. And the upper cast groups normally own more livestock comparing lower caste (Paudelet al., 2007).The survey also revealed that all the traditional healers have strong faith on ethnomedicines although they were less conscious about the documentation and preservation of medicinal plants (Singh et al., 2012).

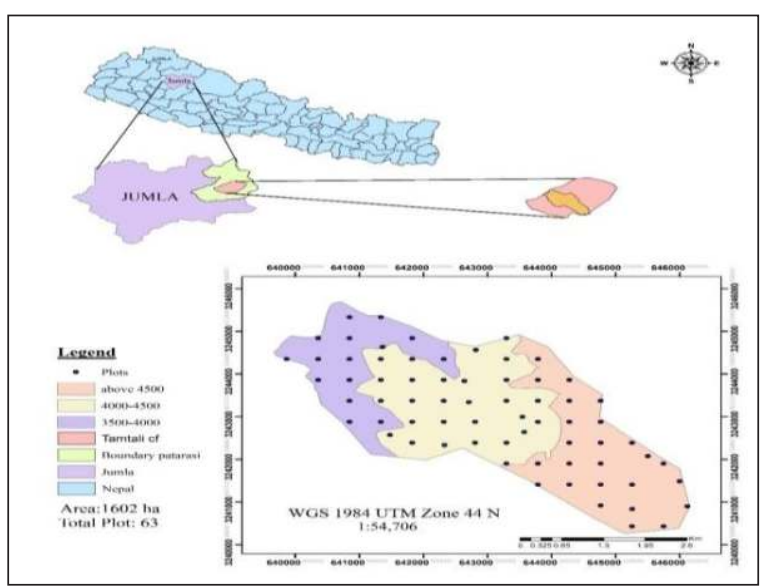

Map 1: Location of Patch of Lamtali CF, Patarashi VDC, Jumla.

\section{Methodology}

The following tasks were completed for the study area:

- The preliminary list of vegetation types expected to occur in the study area was reviewed and refined.

- The altitudinal range of study area was determined through Digital Elevation Model (DEM).
Thus, the present study aimed to assess the distribution of P. kurrooa (Kutki) at different geographical elevation and study about its pattern of collection. Besides, it was also aimed to find the distribution of Kutki in a patch at Lamtali Community forest (CF); to assess the frequency, relative frequency, density, relative density and IVI of Kutki; and to identify collection pattern over different geographical elevation (range).

\section{MATERIALS AND METHODS}

\section{Study area}

The study was conducted in Lamtali CF, which lies in Jumla district of mid-western region Nepal. It is surrounded by the boarders KhadiBijaura at east side, Gadi kola and Phurke CF at west side, Buda Budi Lake at north side and south side is ending with the Chakkhola and the side of PatarasiHimal. Within Lamtali CF area contain all kind of medicinal plant. LamtaliCF covers the 2800 ha area of the patarshi VDC. Within this CF There are three VDC (3,4 and 5) which joined together as a form of CF. Study was caried out within 1602 ha with sampling intensity $0.01 \%$ was taken for fixing sampling plot. Total 63 plot were sample in study area.

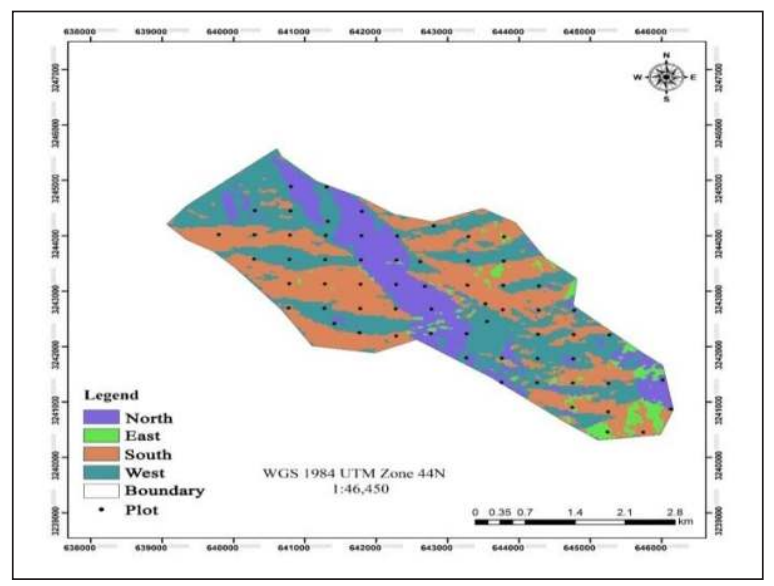

Map 2. Aspect map of Lamtali CF, Patarashi VDC, Jumla

- The stratified systematic sampling was overlaid at the spacing of 500m through GIS analysis applying $0.01 \%$ of sampling intensity, total plot 63 made in the study area.

- The designed plots were identified by X and Y coordinates into GPS. The plot to plot distance was $500 \mathrm{~m}$.

- The plot size $5 \mathrm{~m} \times 5 \mathrm{~m}$ was measured by tape to collect the rhizomes of Kutki. 
- The qualitative data were analyzed by descriptive measurement and were presented in results and discussion part (Table 1). Sampling Design

Table 1: Tabulated flowchart of the procedure adopted.

\begin{tabular}{|c|c|c|c|c|}
\hline S. No. & Research objectives & Field data collection & Process & Remarks \\
\hline 1. & $\begin{array}{l}\text { To find the } \\
\text { distribution } \\
\text { of Kutki in a patch } \\
\text { at Lamtali } \\
\text { Community } \\
\text { forestry(CF). }\end{array}$ & 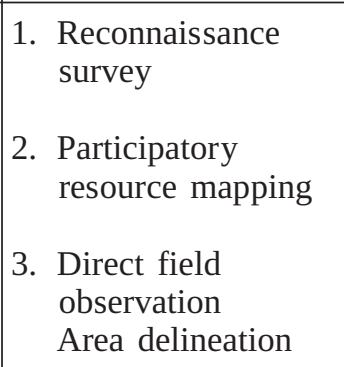 & $\begin{array}{l}\text { - Survey area } \\
\text { Collect data by } \\
\text { counting each } \\
\text { number of herbs of } \\
\text { species. }\end{array}$ & $\begin{array}{l}\text { - } \text { Researcher and } \\
\text { research assistant }\end{array}$ \\
\hline 2. & $\begin{array}{l}\text { To assess the } \\
\text { frequency, relative } \\
\text { frequency, density } \\
\text { and relative density } \\
\text { of Kutki. }\end{array}$ & $\begin{array}{l}\text { 1. Collect data from } \\
\text { field. } \\
\text { 2. Calculate data } \\
\text { according to } \\
\text { formulae. }\end{array}$ & $\begin{array}{l}\text { Using various } \\
\text { software like SPSS } \\
\text { V22, R V 3.2.1 } \\
\text { Software, MS excel } \\
2016 \text { etc. }\end{array}$ & 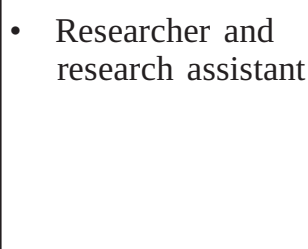 \\
\hline 3. & $\begin{array}{l}\text { To identify collection } \\
\text { pattern over different } \\
\text { geographical } \\
\text { elevations (range). }\end{array}$ & $\begin{array}{l}\text { 1. Key informant } \\
\text { interview }\end{array}$ & $\begin{array}{l}237 \text { hhs ( } 20 \% \text { of } \\
\text { the total hhs in the } \\
\text { study area) include } \\
\text { local collector, old } \\
\text { age people.a }\end{array}$ & $\begin{array}{l}\text { - } \text { Researcher and } \\
\text { research assistant }\end{array}$ \\
\hline
\end{tabular}

\section{Sampling Design}

Stratified transect survey was carried out for the field observation of $P$. Kurrooa by making different strata according to elevation class (range). Within the strata sampling, plots were located made with transect line using the GIS at fixed distance. Sampling plot was carried out on different elevation ranges. Kutki is an herbal plant thus the plot of $5 \mathrm{~m} * 5 \mathrm{~m}$ was laid for the herb to collect sample. Herb (Kutki) was collected during the period from September to November, following the Government of Nepal Non-timber Forest Guidelines 2012 (NTFPs Guideline, 2069) for herb collection. Finally, the available plants (herb) were identified and their number were counted and recorded.

\section{Primary data collection}

A) Key informant survey: Key informants (i.e. FUGs Chairman, VDC leaders and collector) survey was carried out to gather the data regarding distribution of medicinal plants as well as pattern of collection.
Interviews were informal but also consisted of guided questions and close end questions.

B) Group discussion: Group discussions with the farmers were carried out to gather the information regarding the resource status, pattern of collection of Kutki at different elevations and problems related to it.

\section{Secondary Data collection}

Secondary data were collected from different published and unpublished journals, articles, district forest office and concerned community forest of Jumla.

\section{Data analysis}

Data obtained from the field were processed and analyzed manually with the help of Microsoft Excel to find out frequency, relative frequency, density, relative density and Importance Value Index (IVI). The parameters for the distribution and availability of the plants were species richness and abundance while density and frequency were used as indicators. The 
Stratified transect survey was carried out for the field observation of $P$. Kurrooa by making different strata according to elevation class (range). Within the strata sampling, plots were located made with transect line using the GIS at fixed distance. Sampling plot was carried out on different elevation ranges. Kutki is an herbal plant thus the plot of $5 \mathrm{~m} * 5 \mathrm{~m}$ was laid for the herb to collect sample. Herb (Kutki) was collected during the period from September to November, following the Government of Nepal Non-timber Forest Guidelines 2012 (NTFPs Guideline, 2069) for herb collection. Finally, the available plants (herb) were identified and their number were counted and recorded.

\section{Primary data collection}

A) Key informant survey: Key informants (i.e. FUGs Chairman, VDC leaders and collector) survey was carried out to gather the data regarding distribution of medicinal plants as well as pattern of collection. Interviews were informal but also consisted of guided questions and close end questions.

B) Group discussion: Group discussions with the farmers were carried out to gather the information regarding the resource status, pattern of collection of Kutki at different elevations and problems related to it.

\section{Secondary Data collection}

Secondary data were collected from different published and unpublished journals, articles, district forest office and concerned community forest of Jumla.

\section{Data analysis}

Data obtained from the field were processed and analyzed manually with the help of Microsoft Excel to find out frequency, relative frequency, density, relative density and Importance Value Index (IVI). The parameters for the distribution and availability of the plants were species richness and abundance while density and frequency were used as indicators. The frequency of occurrence and density as well as species richness of $P$. kurrooa were determined by using the following formulas:

Frequency $=$ (No. of sample plot in which species occurred / Total Number of sample plot studied) $* 100$ Relative frequency is frequency of a species in relation to other species.
Relative frequency \% = (Frequency of individual species / Total frequency of all species) $* 100$

Density $/$ ha $=$ (Total number of plant of any species /Total number of plot taken* area of sample plot) $* 1000$

Relative density is the density of a species with respect to the total density of all species.

Relative Density \% = $($ Density of individual species /Total density of all species) $* 100$

Importance Value Index = Relative density + Relative frequency + Relative ground cover

\section{RESULT AND DISCUSSION}

From the study in the field, it was observed that the species remained primarily in association with the Padamchal, Panchaule, Jamasi species etc. The other associated species were Pakhanbed, Satuwa etc. Altitudinal range was observed 3000-5000m.

\section{Geographical distribution of $P$. Kurrooa}

Data pertaining to Table 2 shows that $P$. kurrooa has highest frequency $(82.54 \%)$ and $D$. hatagirea has the lowest frequency (7.94\%). P. kurrooa has highest relative frequency and the $D$. hatagirea has lowest relative frequency. The $P$. kurrooa has highest density (7263.492/ha) than the other associated species. The D. hatagirea shows that the lowest density (241.2698/ha). The relative density of $P$. kurrooa is higher (47.93/ha) than the other associated species. The relative density depends upon the occurrence of individual species. D. hatagirea possesses lowest relative density (1.59/ha). The higher IVI value of Kutki than other associate species (113.59) gradually followed by Jatamashi (88.51), Nirmashi (41.91), Padamchal (24.3), Bikh (16) and ultimately Panchaule (15.69).

\section{Aspect-wise distribution of Kutki}

Parametric F test were applied based on one-way ANOVA for the significance test of Kutki with respect to the elevation at $5 \%$ level of significance (Figure 1). The result revealed that there was no significance difference between species with respect to aspect ( $>0.05$ ). Table 3 showed that frequency of Kutki is higher in North aspect then other aspects. 43\% of Kutki is found in north aspect. The lowest frequency was found in south aspect of the study area. If we categorize the study area in eight aspects, the 
frequency was higher in north-west aspect. The highest density of Kutki was observed in east aspect (7476.92/ha) while the lowest density was found in west aspect (7100/ha).

Table 2: Quantitative analysis of Kutki.

\begin{tabular}{|l|c|c|c|c|c|c|c|}
\hline Species & Scientific & Frequency & $\begin{array}{c}\text { Relative } \\
\text { Frequency }\end{array}$ & Density & $\begin{array}{c}\text { Relative } \\
\text { Density }\end{array}$ & Abundance & IVI \\
\hline Kutki & $\begin{array}{c}\text { Picrorhiza } \\
\text { kurrooa }\end{array}$ & 82.54 & 34.44 & 7263.492 & 47.93 & 8800 & 113.59 \\
\hline Pachaule & $\begin{array}{c}\text { Dactylorhiza } \\
\text { hatagirea }\end{array}$ & 7.94 & 3.31 & 241.2698 & 1.59 & 3040 & 15.69 \\
\hline Nirmashi & $\begin{array}{c}\text { Delphinium } \\
\text { denudatum }\end{array}$ & 31.75 & 13.25 & 1612.698 & 10.64 & 5080 & 41.91 \\
\hline Bikh & $\begin{array}{c}\text { Aconitum } \\
\text { spicatum }\end{array}$ & 15.87 & 6.62 & 323.81 & 2.13 & 2040 & 16 \\
\hline Padamchal & $\begin{array}{c}\text { Rheum } \\
\text { australe }\end{array}$ & 26.98 & 11.26 & 660.317 & 4.36 & 2447.06 & 24.3 \\
\hline Jatamashi & $\begin{array}{c}\text { Nardostachys } \\
\text { grandiflora }\end{array}$ & 74.6 & 31.12 & 5053.97 & 33.35 & 6774.47 & 88.51 \\
\hline
\end{tabular}

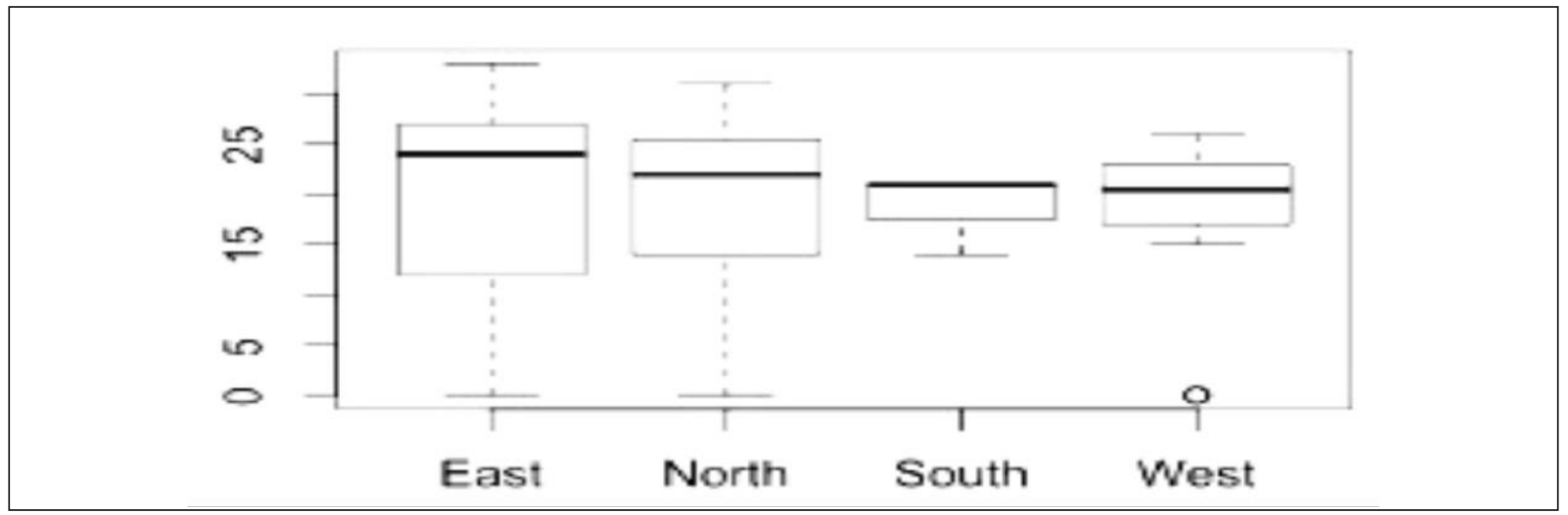

Figure 1: Aspect-wise distribution of $P$. kurrooa.

Table 3: Aspect-wise distribution of Kutki.

\begin{tabular}{|l|c|c|}
\hline Aspects & Frequency & Density \\
\hline North & 42.86 & 7259.26 \\
\hline East & 20.64 & 7476.92 \\
\hline South & 4.76 & 7466.67 \\
\hline West & 31.746 & 7100 \\
\hline
\end{tabular}

\section{Altitude-wise distribution of Kutki}

Parametric F test were applied based on one-way ANOVA for the significance test of Kutki with respect to the elevation at 5\% level of significance (Figure 2). The result revealed that there was significant difference between at least one pair of elevation class. Thus, elevation class 3500m-4000m was significantly different with respect to elevation class $4000 \mathrm{~m}$ $45000 \mathrm{~m}(\mathrm{p}<0.05)$ and the elevation class 4000-4500m was significantly different with respect to elevation $4500 \mathrm{~m}-5000 \mathrm{~m} \quad(\mathrm{p}<0.05)$. While, elevation class $3500 m-4000 m$ was not significantly different with respect to elevation class $4500 \mathrm{~m}-5000 \mathrm{~m}$ ( $\mathrm{p}>0.05$ ). Figure 3 shows that the frequency of Kutki is higher in $4000 \mathrm{~m}-4500 \mathrm{~m}$ elevation range (42. 86\%). Also, the moderate frequency was in 4500m-5000m (28.54\%) and the lowest frequency was in $3500 \mathrm{~m}-4000 \mathrm{~m}$ (11.11\%). 


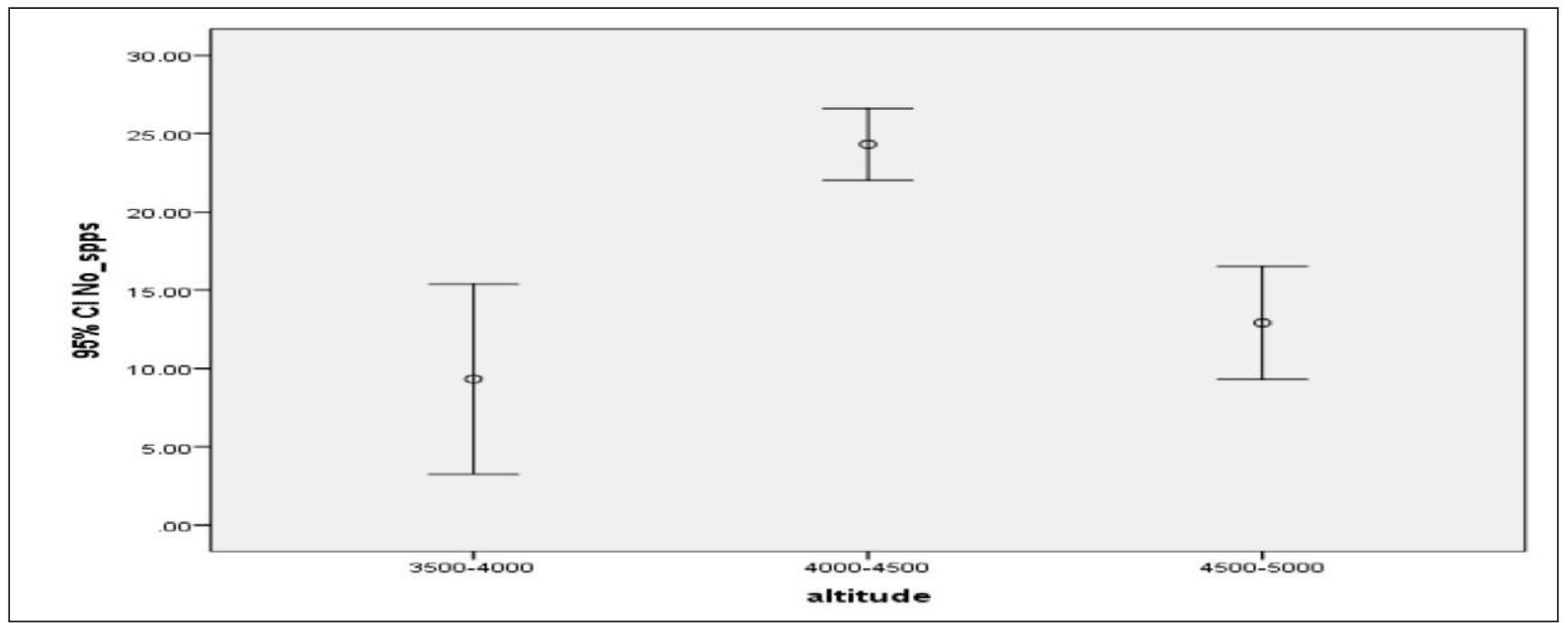

Figure 2: Altitudinal distribution of $P$. kurrooa.

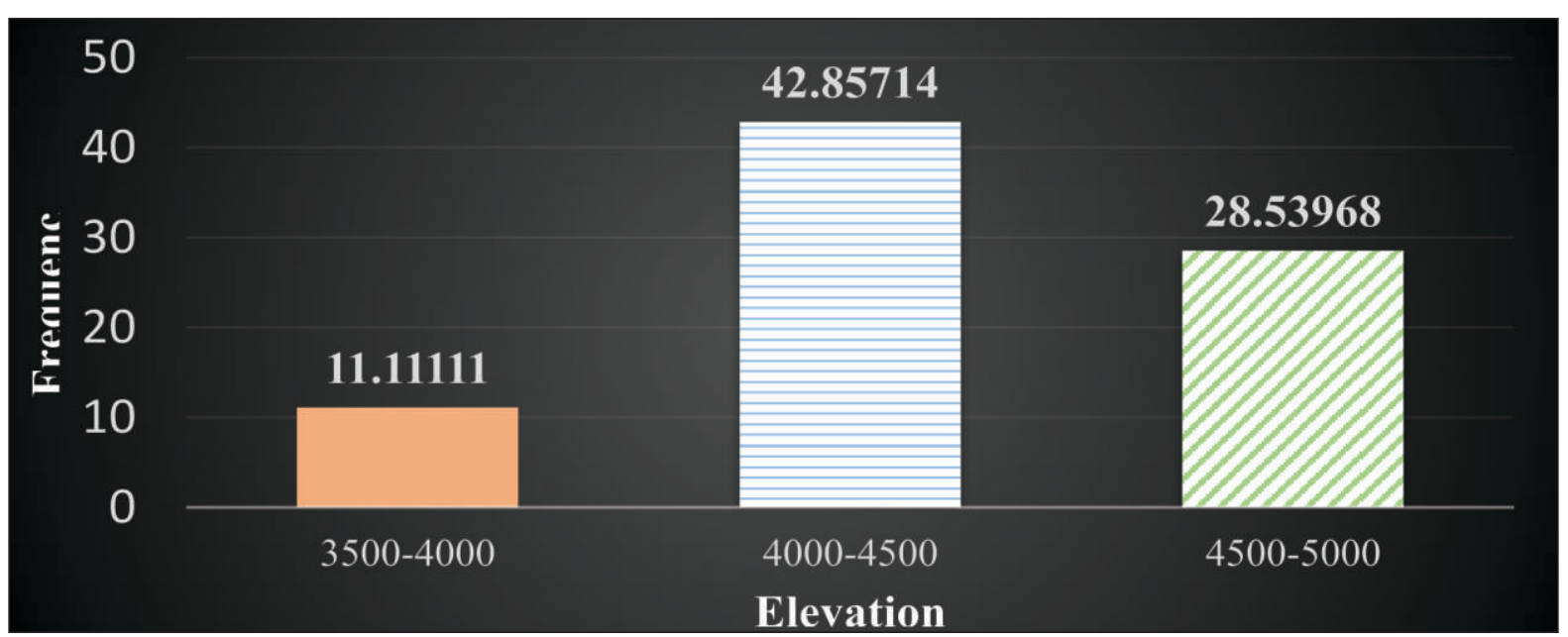

Figure 2: Altitudinal distribution of $P$. kurrooa.

\section{Participation for collection of Kutki}

The Figure 4 shows that the male participation is higher as compared to female. The male participation

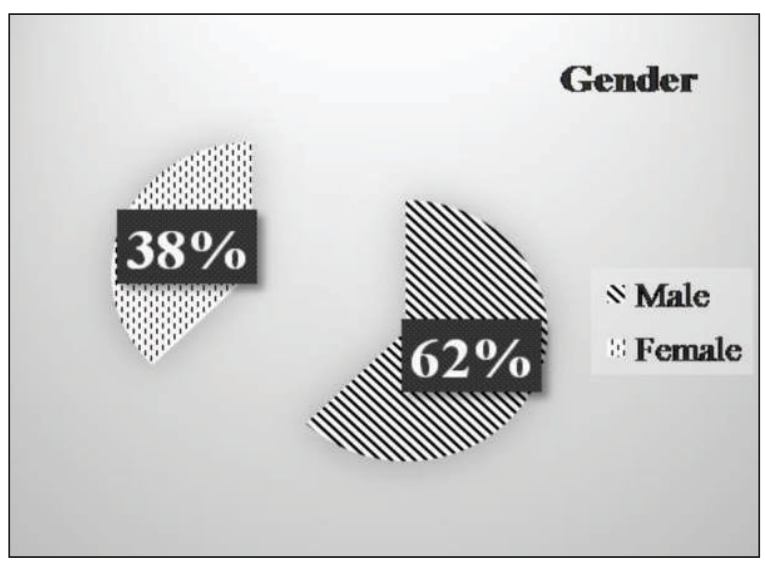

was $62 \%$ while female participation was just $38 \%$ at the study area for collection of Kutki. Age group 20-30 highly travels to collect Kutki.

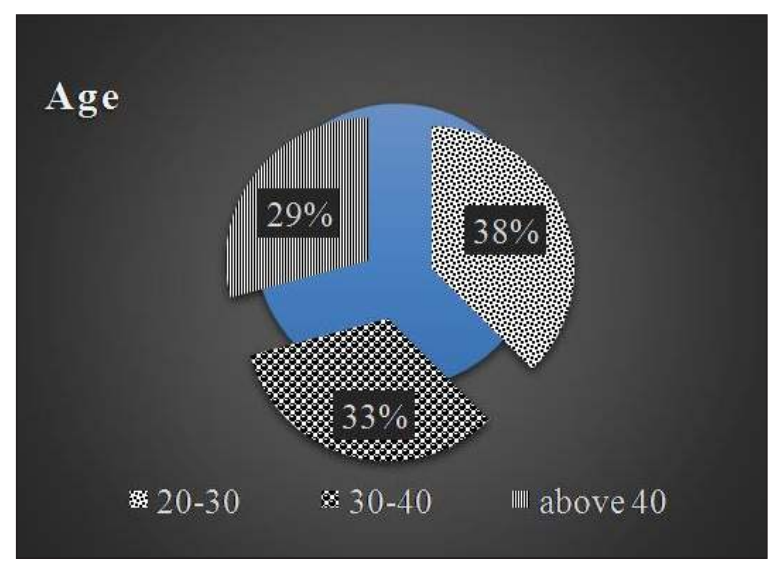

Figure 4. Participation for collection of $P$. Kurrooa. 


\section{CONCLUSIONS}

Picrorhiza kurrooa was mainly distributed in upper parts of the Lamtali CF with associate species Dactylorhiza hatagirea (Panchaule), Delphinium denudatum (Nirmashi), Aconitum spicatum (Bikh), Rheum austral (Padamchal) and Nardostachys grandiflora (Jatamashi). Kutki was found in larger density and higher frequency than other NTFPs. Generally, it was found from $3500 \mathrm{~m}-4500 \mathrm{~m}$ and up to snowline within Lamtali CF. Frequency, relative frequency, density, relative density and IVI were respectively $82.54 \%$, 35\%, 7263.492 , $48 \%$ and 113.59 . The abundance of Kutki was higher than other associate species which was 8800 number/ha. Frequency of Kutki was higher in northern aspect (43\%) and density of Kutki was greater in eastern aspects 7476.92. Frequency of Kutki is higher in 4000$4500 \mathrm{~m}$ elevation range. There was significant difference of average number of Kutki with respect to elevations $(p<0.05)$ but no significant difference with respect to aspects $(\mathrm{p}>0.05)$. Male participation was higher than female for collection of Kutki at Lamtali CF. People from age group 20-30 was mostly involved in the collection of Kutki.

\section{RECOMMENDATIONS}

- CF committee should control the intensive harvesting by making necessary rules.

- DFO should also take initiative in regulating the amount of harvesting at the collection site and ensuring the proper season as well as methods for harvesting of medicinal plants including Kutki.

- Livestock grazing should be managed by stopping the grazing of livestock, or by enforcing to apply for rotational grazing.

- Awareness level of CF users should be increased by clarifying the importance, ecology, sustainable collection, marketing and its impacts on livelihood for sustainable management of Kutki in the study area.

- Community forests of this range need to be managed effectively for economic benefit for the rural populace.

- More effective NTFPs conservation plan is needed for the study area.

- RD and DFO office should be focused for research on high value medicinal plants.

\section{REFERENCES}

1. Acharya, K. P., Chaudhary, R. P., and Vetaas, O. R. (2009): Non-timber forest products from community forestry practices, problems and prospects for livelihood strategy in Jumla, BankoJanakari, 19(1) 16-22.

2. Acharya, R. and Acharya, and K. P. (2009): Ethno-botanical Study of Medicinal Plants Used by Tharu Community of Parroha VDC, Rupandehi District, Nepal. Scientific World, 7(7): 80-84.

3. Arya, D. Bhatt, D. Kumar, R. Tewari, M. L. Kishor, K., and Joshi, G. C. (2013): Studies on natural resources, trade and conservation of Kutki (Picrorhiza Kurrooa Royle ex Benth., Scrophulariaceae) from Kumaun Himalaya, Department of Botany, DSB Campus, Kumaun University, Nainital-263 001, India.

4. Bantawa, P., Saha-Roy, O., Ghosh, S. K. and Mondal, T. K. (2011): In vitro regeneration of an endangered medicinal plant Picrorhiza scrophularii flora. Biol Plant 55:169-172.

5. Bhuju, U. R., Shakya P. R., Basnet, T. B. and Shrestha, S. (2007): Nepal biodiversity resource book. Kathmandu: United Nations Environment Program and Ministry of Environment, Science and Technology, Government of Nepal.

6. CITES, (2014): Convention on International Trade in Endangered Species of Wild Fauna and Flora. March 3, 1973. [Accessed 2014-06-27]. Available from: http://www.cites.org/

7. Dutta, I.C. (2007): No-timber forest products of Nepal... Identification, classification, ethnic use and cultivation. Hill side tress, Kathmandu, Nepal, 84.

8. Ghimire, S. K., Pyakurel, D., Nepal B. K., Sapkota I. B., Parajuli R. R. and Oli, B. R., (2008). A Manual of NTFPs of Nepal Himalaya (Gair Kastha Ban Paidawar Digdarshan). WWF Nepal, Kathmandu, Nepal (In Nepali).

9. Ghimire, S. K., Awasthi, B., Rana, S., Rana, H. and Bhattarai, R. (2015): Status of Exportable, Rare and Endangered Medicinal and Aromatic Plants (MAPs) of Nepal. Report submitted to Department of Plant Resources (DPR), Ministry of Forest and Soil Conservation (MoFSC), Kathmandu, Nepal. 
10. Health Canada, (2015): Wild Animal and Plant Protection and Regulation of International and Interprovincial Trade Act. http://lawslois.justice.gc.ca

11. Hasan, M. K., Gatto, P. and Jha, P. K. (2013): Traditional use of wild medicinal plants and their management practice in Nepal-A study in Makawanpur district, International Journal of Medicinal and Aromatic Plants 04/2013; 3(1):102-112.

12. MoFSC, (2009): Nepal fourth national report to the Convention on Biological Diversity. Kathmandu: Ministry of Forest and Soil Conservation MoFSC, Government of Nepal.

13. Non-timber forest product guideline (2069): Department of forest and soil conservation BabarmahalKathamandu Nepal.

14. Nayar M. P. and Sastri A. R. K. (1990). Red data plants of India. CSIR Publication, New Delhi, 271.

15. Olsen C. S., (2005). Quantification of the trade in medicinal and aromatic plants in and from Nepal. Acta Horticulture, 678:29-35.

16. Pyakurel, D. and Baniya, A. (2011): NTFPs: Impetus for Conservation and Livelihood support in Nepal. A Reference Book on Ecology, Conservation, Product Development, and Economic Analysis of Selected NTFPs of Langtang area in the Sacred Himalayan Landscape. WWF Nepal.

17. Poudel, M. (2007): Non-timber forest products from community forestry practices, problems and prospects for livelihood strategy in Jumla, Banko Janakari, 17(2):45-54.
18. Sah, J. N., Varshney, V. K. and Dutta ,I. C. (2015): "HPTLC assisted evaluation of picroside content in the Accessions of $P$. kurrooagrown at different altitude in Nepal". The Natural Products Journal, 5:82-90.

19. Sah, J. N. and Varshaney, V.K. (2013): Picrorhiza genus review. American journal of Essential and Natural products, 1, 2013.

20. Singh, A. G., Kumar, A. and Tewari, D. D. (2012): An ethno-botanical survey of medicinal plants used in Terai forest of western Nepal.

21. Schippmann U., Leaman and D., Chunningam (2006): "A comparison of cultivation and wild collection of medicinal and aromatic plants under sustainability aspects”. RJ Bogers, LE Craker and D Lange (eds.). Medicinal and Aromatic Plants. Netherlands: Springer (2006): 75-95.11. DPR.

22. Shitiz, K., Pandit, S., Chauhan, R. S. and Sood, H. (2013): Picrosides content in the rhizomes of Picrorhiza kurrooa Royle ex Benth. traded for herbal drugs in the markets of North India. Int $J$ Med Arom Plants. 3(2):226-233.

23. Vaghela, B., Pramar. R., Sonal. H. and Sukhla, L. (2015): Pharmacological activities of $P$. kurrooa. Pharmagene (2), 1.

24. Uniyal, A., Uniyal, S. K. and Rawat, G. S. (2011). Commercial Extraction of Picrorhiza kurrooa Royle ex Benth. in the Western Himalaya: Patterns of Collection. Processing, and Conservation Threats. Mountain Research and Development, 31(3), 201-208. 